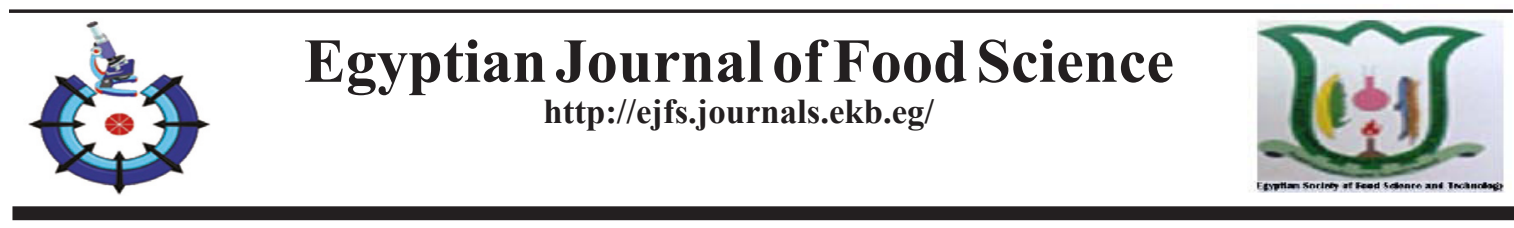

\title{
Production and Evaluation of Lentil Soup and Bissarah
}

Riham H. Abdel-Ghani, Samah A. Abdel Tawab" and Awad A. Mahmoud

Food Science and Technology Department, Faculty of Agriculture, Fayoum University, Fayoum, Egypt.

HE AIM of this study was to production and evaluation of Lentil soup and Bissarah as
precooked foods could be prepared in few minutes.

Shifting to the results, it was reported that dried lintelsoups and Bissarah had high protein content (24.07 and $21.75 \%$ ), potassium is the most predominated elements with values of $797 \mathrm{mg} / 100 \mathrm{~g}$ in dried lentil soup and $546 \mathrm{mg} / 100 \mathrm{~g}$ in Bissarah. HPLC technique showed that Lentil soup and Bissarah were rich in leucine, lysine, and arginine as essential amino acids, as well glutamic and aspartic acids as non-essential amino acids. Result showed that the Bissarah extract had higher total phenolic content, than Lentil soup extract. Gallic acid, Pyrogallol, Vanilline were detected to be the major phenolic components in Bissarah extract meanwhile, Pyrogallol was the predominant in Lentil soup extract. Bissarah and Lentil soup may be good sources of antioxidant agents, which its extracts had the lowest value of $\mathrm{IC}_{50}(1.2$ and $0.77 \mathrm{mg} /$ $\mathrm{ml}$ ) respectively. Antinutritional factors as phytic acid decreased in the end product, as a result of cooking and heat treatment. During storage period for six months there is no a remarkable changes in all of protein, fat, ash and fiber contents in both of dried lintel soup and Bissarah. As well these products were characterized by high microbiological quality where the number of microbes and detection of aflatoxinsare within the Egyptian standard specifications values. Sensory evaluation were acceptable for both lentil soup and Bissarah.

Therefore, we recommend publishing the importance of these food products (dried lintelsoups and Bissarah) as a food rich in minerals, fibers, phenols and antioxidants, at the same time an easy to prepare and inexpensive food.

Keywords : Legumes, Phenolic components, Antioxidant activity.

\section{Introduction}

The modern lifestyle for some people today, such as those living in large cities, needs a fast pace including food preparation and processing. It creates a community that loves instant food products ready to eat. Among the most instant foods, to meet the social requirements of consumers, dried soups play a vital role (Krejov, et al., 2007). Dried foods, such as the mixes of dry soup, are characterized by protection from enzymatic spoilage, oxidative spoilage, and have consistent flavor at the room temperature for long time (El Wakeel, 2007). Solegumes and vegetables added in dried soups to support them with full nutritional value, such as carbohydrates, proteins, fiber and amino acids (Pandey et al., 2006). Legumes are rich sources of carbohydrates, proteins, fats, minerals, fiber, antioxidants and vitamins. Legume seeds have protein contents about of $17 \%-40 \%$, which is typically twice the amount found in cereals and equal protein contents found in meat (18-25\%). Also, They are a good source of lysine but they are poor in sulfur amino acids, such as methionine and cysteine (Swaminathan, 1988).

Health benefits of legumes include protection from cardiovascular disease due to the high content of dietary fiber (Alghamdi, 2009), increased

*Corresponding author : saa06@fayoum.edu.eg

Received :20/12/2019; accepted : 28/1/2019

DOI: 10.21608/EJFS.2020.21201.1033

(C)2020 National Information and Documentation Centre (NIDOC) 
iron absorption because they contain vitamin C (Acar et al., 2009) bone health promotion (Hinterthuer, 2016). Moreover, the whole pulses are a plentiful source of some minerals such as iron, zinc, potassium, phosphorus, selenium, folic acid, isoflavones and tocopherol (Jain et al., 2009). Therefore it is preferable to make pulses as a natural preservative for obesity and related disorders including coronary heart disease, diabetes, metabolic syndrome (Amarowicz, 2008 and Hangen \& Bennink, 2002). It is therefore recommended to take them as part of a healthy eating by health organizations for low index of glycemic (Khan et al., 2008).

Legumes contain a large proportion of biologically active phenolic compounds. The basic phenolic compounds found in legume seeds include condensed tannins, phenolic acids, and flavonoids.

Lentil (seed coat) contains catechins and procyanidins by $70 \%$ of the total phenolic compounds (Singh et al., 2017a).

Phenols play a powerful role as an antioxidant because they are able to scavenge free radicals, break radical chain reactions, and metal chelation, beside its health benefits such as reducing cancers and cardiovascular risks diseases (Han and baik, 2008).

The disadvantage of legume seeds is the presence of phytic acid as anti-nutritional factors, some enzyme inhibitors (trypsin and chymotrypsin proteinase inhibitors), lectins and saponins. Lack of minerals such as (iron, zinc, magnesium) in the human body of the most important health problems caused by these factors (Parca, et al., 2018). Different treatments are common on legumes before consumption, some of which are soaked, boiling, cooked by microwave, extrusion, autoclaving, germination, etc. These treatments affect the anti-nutritional factors such as tannins, trypsin inhibitor activity, phytic acids, hemagglutinin, etc by inhibiting or reducing them (Abbas and Ahmed, 2018).
This study aimed at the production and evaluation of the nutritive values of dried lintel soups and Bissarah.

\section{Materials and Methods}

Materials

The raw materials used in this investigation include:

Mature decorated dehulled Lentils (Lens culinaris) and crushed broad bean (Fava beans) seeds, Fresh tomato (Solanumlycopersicum), yellow carrot (Daucuscarota), onion (Allium cepa), garlic (Allium sativum) and dried Jew's mallow (Corchorusolitorius), Coriander (Coriandrumsativum L), cumin (Cuminumcyminum), black pepper (Piper nigrum) powders and salt were purchased from the local market in Fayoum City, Fayoum governorate, Egypt.

\section{Methods}

\section{Technological treatment}

Preparation of dehydrated precooked foods

(Dried Lentil and dried Bissarah meals):

Both of dehulled Lentil and broad bean matured seed were cleaned, washed then mixed with the rest of ingredients given in Tables 1 and 2 except for cumin in case of Lentil meal and black pepper in case of Bissarah meal. These ingredients were cooked in hot water under pressure at $95^{\circ} \mathrm{C}$ for $15 \mathrm{~min}$, cool the mixture and mix well using Braun Multiquick Blender. The mixture then screened using screen for separating any pomace. uniqueness of the resulting dough on aluminum trays and then dried in hot air flow oven, in the first four hours at $70^{\circ} \mathrm{C}$ and then reduced to $50{ }^{\circ} \mathrm{C}$ until complete drying.

The dried blends were milled using a laboratory mill and seasoned with cumin powder for Lentil soup and black pepper powder for Bissarah and sieved through 60 mesh sieve into powdered form. Keep these powders in polyethylene bags at room temperature for 6 months. At regular intervals (Bimonthly) Various analyzes are conducted.

TABLE 1. Lentil meal recipe.

\begin{tabular}{lc}
\hline Ingredient & gm \\
\hline Dehulled Lentil & 100 \\
Fresh tomato & 20 \\
Fresh onion & 7 \\
Fresh yellow carrot & 20 \\
Fresh garlic & 3 \\
Salt & 4 \\
Cumin powder & 5 \\
Water & 100 \\
\hline
\end{tabular}

Egypt. J. Food Sci. 48, No.1 (2020) 
TABLE 2. Bissarah meal recipe.

\begin{tabular}{lc}
\hline Ingredient & gm \\
\hline Dehulled crushed broad bean & 100 \\
Fresh onion & 10 \\
Fresh tomato & 15 \\
Dried jew's mallow powder & 5 \\
Fresh garlic & 3 \\
Black pepper powder & 0.5 \\
Coriander powder & 2 \\
Salt & 4 \\
Water & 100 \\
\hline
\end{tabular}

Chemical analysis

Proximate chemical composition

Moisture, lipids, ash, fiber and protein were determined according to AOAC methods (2000). Nitrogen free extract NFE (Carbohydrates) was calculated by difference using the following equation.

$$
\begin{gathered}
\text { NFE }(\%)=100-(\% \text { Moisture }+ \text { Protein }+ \text { Fat }+ \\
\text { Ash }+ \text { Fiber }) .
\end{gathered}
$$

\section{Caloric values}

Caloric values of the prepared products (Lentil and Bissarah) were calculated according to the method suggested by Dougherty et al. (1988). Energy (E) equals calories per 100 g product were calculated using the following equation:

$$
\begin{gathered}
\mathrm{E}_{\mathrm{kca} / 100 \mathrm{~g}}=4(\text { protein } \%+\text { nitrogen free extract } \%) \\
+ \text { fat } \% \text { × } 9
\end{gathered}
$$

\section{Determination of minerals}

Sample preparation

About of $0.2-0.3 \mathrm{~g}$ of ground sample was weighed into the polytetrafluoroethylene digestion vessel add $5 \mathrm{~mL}$ of concentrated $\mathrm{HNO}_{3}$ and $2 \mathrm{~mL}$ of hydrogen peroxide $\left(\mathrm{H}_{2} \mathrm{O}_{2}\right)$. Subsequently, the digestion of samples is carried out on a two-step temperature program. The temperature increased until $190^{\circ}$, cover $10 \mathrm{~min}$ in the first step. During the second step, the temperature was maintained at $190{ }^{\circ} \mathrm{C}$ for $30 \mathrm{~min}$. After digestion, must cool the solution and evaporated to $2 \mathrm{~mL}$ and diluted with deionized water in a 50 - $\mathrm{mL}$ volumetric flask for the Atomic Absorption Spectroscopy analysis. Obtained results as the average of three repeated measurements, as well, all digestions were performed in triplicate.

\section{Instruments}

An Agilent atomic absorption spectrometer equipped with Agilent single-element hollow cathode lamps and a $10-\mathrm{cm}$ air-acetylene burner was used for the determination of the metal ions.

\section{Determination of amino acids}

Determination of amino acids by the method described by Spackman et al. (1963).

\section{Determination of total phenolic conents (TPC) \\ Extraction}

The TPC in samples, $10 \mathrm{~g}$ of each defatted powdered samplewere extracted individually at room temperature $\left(\sim 25{ }^{\circ} \mathrm{C}\right)$ with $100 \mathrm{~mL}$ absolutemethanol. Filter the extracts through filter paper Whatman No 1 using rotary evaporator at 45 $\pm 5^{\circ} \mathrm{C}$ to evaporate the solvents, and the driedmatter was storage at $-20^{\circ} \mathrm{C}$ for further determinations.

\section{Quantification and identification of phenolic contents}

TPC in the extracts were determined by the FolinCiocalteu method according to Singleton and Rossi (1965).

The separation of phenolic acids and flavonoids were performed with an Agilent 1260 Infinity series HPLC according to Hakkinen et al. (1998).

\section{Determination of antioxidant activity}

Measuring the DPPH radical in the extract by the method explained by Brand-Williams et al., (1995). An aliquot of $0.1 \mathrm{ml}$ of the extracted fraction was mixed with $3.9 \mathrm{ml}$ of freshly prepared DPPH in a concentration of $60 \mu$ mols in methanol. After $30 \mathrm{~min}$. incubation at ambient temperaturein the dark, the resultant absorbance was measured at $515 \mathrm{~nm}$. All determinations were performed in triplicate. The percentages of inhibition of the DPPH radical were calculated by the following equation :

Egypt. J. Food Sci. 48, No.1 (2020) 


$$
\% \text { Inhibition }=\mathrm{A}_{\mathrm{co}}-\mathrm{A}_{\mathrm{At}} \backslash \mathrm{A}_{\mathrm{co}} \mathrm{X} 100
$$

Where : $\mathrm{A}_{\mathrm{co}}$ : the control absorbance at $\mathrm{t}=0$. $A_{A t}$ : the samples absorbance at $t=30 \mathrm{~mm}$.

All the antioxidants needed to reduce the DPPH radical concentration by $50 \%\left(\mathrm{IC}_{50}\right)$, and the antiradical power (ARP), were calculated which equals $1 / \mathrm{IC}_{50}$.

\section{Phytic acidcontent}

The determination of phytic acidcontent in samples as antinutation factors was performed by the method explained by Haug and Lantszch (1983). Samples with solution of acidic ammonium iron-III sulphate (known concentration).were heated Using 2, 2 bipyridine at wavelength $519 \mathrm{~nm}$ through spectrophotometer.

\section{Determination of aflatoxin}

aflatoxin was determinated by measuring on Agilent Technologies 1260 series HPLC with UV detection as explained by Makun et al., (2012).

\section{Microbiological Examination}

The experimental samples of dried Lentil soup and Bissarah were analyzed for the following microbial counts : mesophilic, thermophilic, coliform group, yeast and moulds, were determined according APHA (1992). At regular intervals a microbiological analysis was performed for 6 months of storage.

\section{Sensory evaluation}

The rehydrated soup samples were sensory evaluated after dissolving in hot water $(10 \mathrm{~g}$ dried soup mixtures / $65 \mathrm{ml}$ of water) the sensory properties, were i.e. taste, flavor, thickness, color, Trend to separation and overall acceptability. The assessment was carried out by 10 panelists of the Food Science and Technology Department, Faculty of Agriculture, Fayoum University according to Kramer and Twigg (1974).The numerical scale was: Excellent $\geq 8.5$; very good 7-8.4; good 6-6.9; fair 5-5.9; poor 4-4.9 and very poor $\leq 3.9$. Analyzed statistically the data obtained from sensory evaluation by ANOVA (Snedecorand Cochran, 1980).

\section{Results and Discussion}

\section{Proximate chemical composition}

Pulse crops including Lentil and broad beans are an excellent source of protein, carbohydrates, and fiber. They provide many essential vitamins and minerals. The major chemical composition of the investigated main raw materials and their final products are given in Table 3. The data show that the unprocessed materials, Lentil and broad bean had higher moisture content (10.57 and 11.33\%) compared to the end products, dried Lentil soup $(7.59 \%)$ and Bissarah (6.63\%). These results are in accordance with that of Egyptian Standard (2003) demonstrating that moisture content of dehydrated bouillons must not exceed $6 \%$. Results presented in Table 3 indicate that the Lentil and Lentil soup had highest protein content (27.38 and $23.15 \%$ ) compared to broad bean and Bissarah, (24.07 and $21.75 \%$ ). The obtained results are in harmony with that detected by (Hayat et al., 2014).

TABLE 3. Proximate chemical composition of lentil, broad bean and their products.

\begin{tabular}{lcccc}
\hline \multirow{2}{*}{ Component (\%) } & \multicolumn{4}{c}{ Investigated samples } \\
\cline { 2 - 5 } & Lentil & Dried Lentil Soup & Broad Bean & Dried Bissarah \\
\hline Moisture & $10.57 \pm 0.99$ & $7.59 \pm 0.92$ & $11.33 \pm 1.24$ & $6.63 \pm 1.36$ \\
Crude protein & $27.83 \pm 2.25$ & $23.15 \pm 3.52$ & $24.07 \pm 2.90$ & $21.75 \pm 4.42$ \\
Crude lipids & $1.02 \pm 0.86$ & $0.78 \pm 0.28$ & $1.42 \pm 1.25$ & $1.06 \pm 0.81$ \\
Crude fiber & $2.18 \pm 1.69$ & $3.27 \pm 1.54$ & $2.67 \pm 1.21$ & $3.87 \pm 1.55$ \\
Ash & $2.56 \pm 1.27$ & $5.11 \pm 1.38$ & $3.26 \pm 1.01$ & $5.34 \pm 1.52$ \\
Nitrogen Free Extract & 66.41 & 67.69 & 68.58 & 67.98 \\
$\begin{array}{l}\text { Total caloric energy } \\
\quad(K \text { cal } / 100 \text { g) }\end{array}$ & 386.14 & 370.38 & 383.38 & 368.46 \\
\hline
\end{tabular}

Egypt. J. Food Sci. 48, No.1 (2020) 
Crude fiber of the investigated samples, shown in Table 3 clearly indicated that the values of crude fiber were 2.18 and $3.27 \%$ for lentil and dried lentil soup respectively. While Broad bean and dried Bissarah have values of 2.67 and $3.87 \%$, respectively. The end products had fiber content higher than the raw materials may be due to added fiber-rich vegetables.

Nitrogen free extract as carbohydrates calculated by difference in the tested samples, values obtained showed the samples contain nearest values of carbohydrates. Such finding coincides with that obtained by El-Wakeel (2007) who found that the carbohydrate of Lentil was $66.41 \%$.

It can be concluded that from the chemical analysis the samples examined contain responsible contents of the required nutrients especially protein and carbohydrates as a source of energy needed by adults and children. So, the total energy value of both Lentil soup and Bissarah being (370.8 and $383.38 \mathrm{k}_{\text {cal }} / 100 \mathrm{~g}$ ) respectively.

\section{Mineral elements content}

The mineral contents calculated as $\mathrm{mg} / 100 \mathrm{~g}$ on dry basis of the dried Lentil soup and Bissarah are illustrated in Table 4. The dried Lentil soup had the maximum levels of the elements content compared to Bissarah. Potassium is the most predominated elements with values of 797.0 $\mathrm{mg} / 100 \mathrm{~g}$ for dried Lentil soup and $546.0 \mathrm{mg} / 100 \mathrm{~g}$ for Bissarah.

Dried Lentil soup had medium amounts of phosphorus, magnesium and calcium; the values were 263,207 and $128 \mathrm{mg} / 100 \mathrm{~g}$, respectively. While dried Bissarah had values of $185,94.4$ and $85 \mathrm{mg} / 100 \mathrm{~g}$ for phosphorus, magnesium and calcium, respectively.
Meanwhile, the lowest values of elements for zinc was 3.7 and $2.4 \mathrm{mg} / 100 \mathrm{~g}$ in dried Lentil soup and Bissarah, respectively. While iron had higher amounts compared to zinc ( 8.6 and $6.3 \mathrm{mg} / 100 \mathrm{~g}$ ) in dried Lentil soup and Bissarah respectively. These results revealed that Lentil soup and Bissarahmay be a source of minerals needed by the body.

Such finding coincides with that obtained by Iqbal et al. (2006) and Zia-Ul-Haq et al. (2011).

\section{Amino acid composition}

Legume seeds have high amount of proteins and consequently amino acids. The value of food products is assessed by the amounts of essential amino acids. Amino acids composition expressed in ( $\mathrm{g}$ amino acid / $16 \mathrm{~g}$ nitrogen) of dried Lentil soup and dried Bissarah was determined and the obtained results are given in Table 5.

As for essential amino acids, data given in Table 5 shows that arginine, lysine and leucine were found in high level in dried Lentil soups (6.94, 6.2 and $5.19 \mathrm{~g} / 16 \mathrm{~g} \mathrm{~N})$ and Bissarah (7.94, 5.9 and $5.54 \mathrm{~g} / 16 \mathrm{~g} \mathrm{~N}$ ) respectively. There are medium quantities of phenylaniline and valinein Lentil soup (4.1 and $4.92 \mathrm{~g} / 16 \mathrm{~g} \mathrm{~N}$ ) and Bissarah (4.87 and $3.91 \mathrm{~g} / 16 \mathrm{~g} \mathrm{~N}$ ) respectively. On the other hand, the results given in Table (5) shows that all of Lentil soup and Bissarah had lower quantities from methionine ( 0.75 and 0.61$)$ and tryptophan $(0.65$ and $0.41 \mathrm{~g} / 16 \mathrm{~g} \mathrm{~N})$ respectively.

As for non-essential amino acids, glutamic and aspartic acids was the most predominated in Lentil soup (13.85 and $9.17 \mathrm{~g} / 16 \mathrm{~g} \mathrm{~N}$ ) and Bissarah (14.27 and $13.35 \mathrm{~g} / 16 \mathrm{~g} \mathrm{~N}$ ) respectively.

TABLE 4. Mineral elements content as (mg/100g) of dried Lentil soup and Besarahon dry basis.

\begin{tabular}{lcc}
\hline Component & $\begin{array}{c}\text { Dried } \\
\text { Lentil soup }\end{array}$ & $\begin{array}{c}\text { Dried } \\
\text { Bissarah }\end{array}$ \\
\hline Calcium & $128.0 \pm 18.52$ & $85.0 \pm 13.75$ \\
Magnesium & $207.0 \pm 55.11$ & $94.4 \pm 16.52$ \\
Potassium & $797.0 \pm 104.01$ & $546.0 \pm 57.16$ \\
Phosphorus & $263.0 \pm 101.34$ & $185.0 \pm 58.95$ \\
Zinc & $3.7 \pm 1.08$ & $2.4 \pm 1.00$ \\
Iron & $8.6 \pm 1.57$ & $6.3 \pm 2.07$ \\
\hline
\end{tabular}


TABLE 5. Amino acid composition of dried Lentil soup and dried Bissarah (g/16 g N).

\begin{tabular}{|c|c|c|}
\hline Amino acid & $\begin{array}{c}\text { Dried } \\
\text { Lentil Soup } \\
\end{array}$ & $\begin{array}{c}\text { Dried } \\
\text { Bissarah } \\
\end{array}$ \\
\hline \multicolumn{3}{|c|}{ Essential Amino Acid (EAA) } \\
\hline Leucine & 5.19 & 5.54 \\
\hline Isoleucine & 2.12 & 2.38 \\
\hline Lysine & 6.2 & 5.9 \\
\hline Methionine & 0.75 & 0.61 \\
\hline Phenylaniline & 4.13 & 4.87 \\
\hline Therionine & 2.89 & 3.07 \\
\hline Tryptophan & 0.65 & 0.41 \\
\hline Valine & 4.92 & 3.91 \\
\hline Arginine & 6.94 & 7.94 \\
\hline Histidine & 1.8 & 2.75 \\
\hline \multicolumn{3}{|c|}{ Non-Essential Amino Acid (NEAA) } \\
\hline Alanine & 3.98 & 4.85 \\
\hline Aspartic acid & 9.17 & 13.35 \\
\hline Cysteine & 0.63 & 0.85 \\
\hline Glutamic acid & 13.85 & 14.27 \\
\hline Glycine & 2.98 & 7.34 \\
\hline Proline & 3.12 & 3.35 \\
\hline Serine & 5.73 & 6.04 \\
\hline Tyrosine & 2.83 & 2.54 \\
\hline
\end{tabular}

Also, from the aforementioned data it could be noticed that both of dried Lentil soup and Bissarah are rich in acidic amino acids (aspartic and glutamic), leucine, lysine, and arginine but poor in amino acids containing sulpher and tryptophan. These data are parallel to that achieved by by Swaminathan 1988 and Al-Tonny (2012).

Total phenolic compounds and antioxidant properties

The total phenolic content (TPC) in extracts of dried Lentil soup and Bissarah expressed as (mg gallic acid equivalent/g dry mass) and antioxidant activity expressed as $\mathrm{IC}_{50}$ and the antiradical power (ARP) the shown in Table 6.

From Table 6, it was clear that the Bissarah extract had the highest value of TPC $(61.4 \mathrm{mg}$ GAE/g), while Lentil soup extract had (50.04 mg $\mathrm{GAE} / \mathrm{g}$ ) of TPC. Regarding to antioxidant activity the obtained results show that the Bissarah extract had (1.3) ARP and (0.77) $\mathrm{IC}_{50}$ as compared to Lentil soup extract which had (0.83) ARP and (1.2) $\mathrm{IC}_{50}$.

The higher the ARP, the lower the $\mathrm{IC}_{50}$ and vice versa because high ARP values indicate that high efficiency as antioxidants. The differences in antioxidant activity of phenolic compound is directly affected of chemical structures as the number and position of the attached hydroxyl groups and the degree of glycosylation with respect to Carboxyl functional group (Aguilera et al., 2011).

Generally, it could be concluded that dried Lentil soup and Bissarahcould be a rich source of effective antioxidants against fighting free radicals which are detrimental to human health.

Egypt. J. Food Sci. 48, No.1 (2020) 
TABLE 6. Total phenolic content and DPPH scavenging activity of Lentil soup and Bissarah.

\begin{tabular}{|l|c|c|}
\hline Parameter & Lentil soup & Bissarah \\
\hline Total phenols as gallic acid (mg/g) & $50.04 \pm 7.17$ & $61.40 \pm 10.25$ \\
\hline $\mathbf{I C}_{\mathbf{5 0}}$ * & $1.2 \pm 0.27$ & $0.77 \pm 0.23$ \\
\hline $\mathbf{A R P} * *$ & $0.83 \pm 0.24$ & $1.3 \pm 0.20$ \\
\hline
\end{tabular}

* The amount of antioxidant necessary to decrease the initial DPPH concentration by $50 \%$.

** The antiradical power (ARP)

Individual phenolic compounds identification

Gallic acid, Pyrogallol, Resorcinol, Caffeic Acid, Vaniline, Salicylic acid, Cinnamic acid and Quarecetinas Individual phenolic identification in methanolic extract of Lentil soup and Bissarahwere recognized and the obtained results are presented in Table 7.

Gallic acid, Pyrogallol, Vanilline were detected to be the major phenolic components, values were $33.61,32.51$ and $31.07 \mathrm{mg} / \mathrm{g}$, respectively in Bissarah extract. On the contrary, Gallic acid was detected to be the minor phenolic component in Lentil soup extract, the value was $4.84 \mathrm{mg} / \mathrm{g}$. Pyrogallol was the predominant in Lentil soup extract, value about $39.17 \mathrm{mg} / \mathrm{g}$. meanwhile, Vanilline was found to be absent in Lentil soup extract. Lentil soup had the highest values of Resorcinol and Cinnamic acid contributing about 50.81 and $13.44 \mathrm{mg} / \mathrm{g}$ compared to Bissarah extract which had 7.91 and $11.11 \mathrm{mg} / \mathrm{g}$, respectively. But, Bissarah extract had the highest values of Salicylic acid and Quarecetin contributing about 23.53 and $19.88 \mathrm{mg} / \mathrm{g}$ compared to Lentil soup extract which had 8.68 and $7.59 \mathrm{mg} / \mathrm{g}$, respectively.

This can be referred that Bissarah extract had high percentage of most studied phenolic components compared to Lentil soup.

\section{Antinutritional factors in dried lentil soup andBissarah}

Phytic acid is an ant-nutritional agent which, form complex with food minerals such as calcium, zinc, iron, and magnesium making it nonabsorbable. Also linked to (proteases and alphaamylase) as inhibit digestive enzymes (Angel et al., 2002 and Mudgil \& Barak, 2013).

Data given in Table 8 show that raw broad bean had the highest content of phytic acid $(16.43 \mathrm{mg} / \mathrm{g}$ ) compared to raw Lentil seeds (2.93 $\mathrm{mg} / \mathrm{g}$ ). There was a decrease of this ratio in the final product and the decrease ratio was $89.41 \%$ and $84.30 \%$ in dried Bissarah and Lentil soup, respectively.
Our results are parallel with the results of (Vidal-Valverde et al., 1994) who suggested that cooking soaked lentil seeds in water led to complete removed to Trypsin inhibitor and reduced Phytic acid.

Legumes do not consume before conducting various treatments some of which are soaked, boiling, extrusion, autoclaving, germination, etc. These treatments showed inhibition or reduction of anti-nutritional factors such as tannins, trypsin inhibitor activity, phytic acids, hemagglutinin, ...etc (Abbas and Ahmed, 2018).

Keeping quality of dried Lentil soup and Bissarah during storage

The shelf life of the product is not fixed but may change depending on storage conditions. The most important of these conditions such as temperature, but other conditions such as package attributes, atmospheric humidity and exposure to light, may all be important for specific foods (Richardson, 1986).

Samples were stored in polyethylene bags for six months at room temperature, and analyzed at regular intervals every two months, for chemical composition and microbiological count, results obtained in the Tables 9 and 10 .

\section{Changes in chemical composition during srtorage}

Data presented in Table 9 show that the moisture content of the samples increased slightly during the storage period, but this increase is still in the safe side.

Moisture content of Lentil soup increased slightly from 7.56 at the beginning of storage to 7.84 at the end of storage at room temperature. The same trend it was noticed in Bissarah, moisture content increased from 6.63 at the beginning of storage to 7.22 after 6 months of storage.

Egypt. J. Food Sci. 48, No.1 (2020) 
TABLE 7. Phenolic components content of Lentil and Bissarah extracts expressed as (mg/g dry mass).

\begin{tabular}{lcc}
\hline \multirow{2}{*}{ Component } & \multicolumn{2}{c}{ Concentration (mg / g) } \\
\cline { 2 - 3 } Gallic acid & Lentil soup & Bissarah \\
Pyrogallol & 4.84 & 33.61 \\
Resorcinol & 39.17 & 32.51 \\
Caffeic Acid & 20.81 & 7.91 \\
Vaniline & nd & nd* \\
Salicylic acid & nd & 31.07 \\
Cinnamic acid & 8.68 & 23.53 \\
Quarecetin & 13.44 & 11.11 \\
\hline nd*: not detected & 7.59 & 19.88 \\
\hline
\end{tabular}

TABLE 8. Antinutritional factors in lentil, dried lentil soup, broad bean and Bissarah.

\begin{tabular}{ccccccc}
\hline $\begin{array}{c}\text { Reduction } \\
\text { Rate }\end{array}$ & $\begin{array}{c}\text { Dried } \\
\text { Bissarah }\end{array}$ & $\begin{array}{c}\text { Broad } \\
\text { Bean }\end{array}$ & $\begin{array}{c}\text { Reduction } \\
\text { Rate }\end{array}$ & $\begin{array}{c}\text { Dried lentil } \\
\text { Soup }\end{array}$ & Lentil & Antinutrient \\
\hline 89.41 & $1.74 \pm 0.33$ & $16.43 \pm 2.50$ & 84.30 & $0.46 \pm 0.15$ & $2.93 \pm 1.43$ & $\begin{array}{c}\text { Phytic acid } \\
(\mathbf{m g} / \mathbf{g})\end{array}$ \\
\hline
\end{tabular}

TABLE 9. Changes in chemical composition of dried lentil soup and Bissarah during storage period.

\begin{tabular}{|c|c|c|c|c|c|}
\hline \multicolumn{4}{|c|}{ Storage period (month) } & \multirow{2}{*}{ Sample } & \multirow{2}{*}{ Constituent (\%) } \\
\hline 6 & 4 & 2 & $\mathbf{0}$ & & \\
\hline $7.84 \pm 1.10$ & $7.69 \pm 1.20$ & $7.62 \pm 1.173$ & $7.59 \pm 1.13$ & Lentil soup & \multirow{2}{*}{ Moisture } \\
\hline $7.22 \pm 1.51$ & $7.01 \pm 1.55$ & $6.82 \pm 1.73$ & $6.63 \pm 1.66$ & Bissarah & \\
\hline $23.25 \pm 3.450$ & $23.18 \pm 3.480$ & $23.17 \pm 3.490$ & $23.15 \pm 3.50$ & Lentil soup & \multirow{2}{*}{ Protein } \\
\hline $21.95 \pm 4.54$ & $21.86 \pm 4.56$ & $21.79 \pm 4.45$ & $21.75 \pm 4.42$ & Bissarah & \\
\hline $0.83 \pm 0.29$ & $0.81 \pm 0.29$ & $0.80 \pm 0.29$ & $0.78 \pm 0.28$ & Lentil soup & \multirow{2}{*}{ Fat } \\
\hline $1.18 \pm 0.71$ & $1.15 \pm 0.74$ & $1.13 \pm 0.75$ & $1.06 \pm 0.81$ & Bissarah & \\
\hline $5.23 \pm 1.29$ & $5.19 \pm 1.29$ & $5.17 \pm 1.29$ & $5.11 \pm 1.38$ & Lentil soup & \multirow{2}{*}{ Ash } \\
\hline $5.52 \pm 1.32$ & $5.43 \pm 1.42$ & $5.38 \pm 1.47$ & $5.34 \pm 1.52$ & Bissarah & \\
\hline $3.38 \pm 1.57$ & $3.35 \pm 1.63$ & $3.30 \pm 1.69$ & $3.27 \pm 1.68$ & Lentil soup & \multirow{2}{*}{ Fiber } \\
\hline $4.11 \pm 1.35$ & $4.06 \pm 1.47$ & $3.93 \pm 1.59$ & $3.87 \pm 1.54$ & Bissarah & \\
\hline 59.47 & 59.78 & 59.94 & 60.1 & Lentil soup & \multirow{2}{*}{ N Free Extract } \\
\hline 60.02 & 60.49 & 60.95 & 60.35 & Bissarah & \\
\hline
\end{tabular}


Concerning the protein, fat, ash and fiber contents there is no a remarkable changes in these chemical constituents in the both product approximately remained constant during 6 months ofstorage period may be due tothe control of storage conditions such as temperature and relative humidity.

Change in microbiological count during storage

The effect of storage period at room temperature on growth of microbial population of dried Lentil soup and dried Bissarah was studied and the obtained results are presented in Table 10.

Table 8 demonstrated that dried Lentil soup had higher total mesophilic aerobic bacteria count than Bissarah, which the count increased gradually with the prolongation of time. Where, dried lentil soup had total count increased from $2.1 \times 10^{3}$ in the beginning to $4.5 \times 10^{4}$ at the end of storage period. The same trend it was noticed for Bissarah, the total count increased from $8.3 \mathrm{x}$ $\left.10^{2} \mathrm{cfu} / \mathrm{g}\right] \backslash$ at in the beginning to $3.7 \times 10^{3}$ after six months of storage.

The results of thermophilic bacteria count in both of dried Bissarah and Lentil soup less than $100 \mathrm{cfu} / \mathrm{g}$ during the storage period.

Also, regarding to yeast and mould, Lentil soup exhibited slightly higher mold and yeast count than Bissarah. It was obvious slightly increase in yeast and mould count in both of investigated samples with the prolongation of storage period. Coliform group was detected at a few numbers ranged from ndto $7 \mathrm{cfu} / \mathrm{g}$ in both investigated samples. Such finding coincides with that obtained by Al-Tonny (2012).

The low microbial count of dried Bissarah may be attributed to the low moisture content and the high total phenolic content which have antimicrobial effect such as phenolicacids, cinnamic acid (Nakajima et al. 2009 and Telles, et al., 2017).

The differences in microbiological count of these products may be due to the differences in type of the raw materials (vegetables and spices) used in processing these products.

From the aforementioned data it could be concluded that the obtained values of microbiological count of investigated products in this work was acceptable by Egyptian standards (2007).
Microbiological count of dried Lentil soup and Bissarah duringstorage period atroom temperature Total aflatoxins

Aflatoxin can be formed in dried foods such as spices as a result of fungal contamination before and after harvest.

Various Aflatoxins e.g., $G_{1}, G_{2}, B_{1}, B_{2}$ were detected in the studied samples and the results illustrated in Table 11.

The data presented in Table 11 show that Bissarah had the highest values of $G_{1}, G_{2}, B_{1}, B_{2}$ and total aflatoxins $(0.68 \mathrm{ppb})$ compared to Lentil soup $(0.20 \mathrm{ppb})$. The obtained values were very low than the recommended level $(10 \mathrm{ppb})$ in the Egyptian Standards (2007).

Also, the Food and Drug Administration (FDA) has set maximum permissible levels of total aflatoxin in food at $20 \mathrm{ppb}$.

Aflatoxin B1 among the different aflatoxins, is predominant in the Bissarah sample contributing about 0.25 ppb followed by $B_{2}$ and $G_{1}$ contributing about $0.16 \mathrm{ppb}$ for each one followed by $\mathrm{G}_{2}$ contributing about $0.11 \mathrm{ppb}$. While aflatoxin G2 is predominant in lentils soup followed by $G_{1}$ contributing $0.07 \mathrm{ppb}$ followed by aflatoxins $\mathrm{B}_{1}$ and $\mathrm{B}_{2}$ contributing about $0.02 \mathrm{ppb}$ for each one.

The presence of aflatoxin in both dried Lentil soup and Bissarah may be due to spices found by Fazekas et al. (2005) that spices are usually contaminated with mycotoxins. Home cooking such as boiling and frying (approx. $150^{\circ} \mathrm{C}$ ) failed to destroy aflatox in $B_{1}$ and $G_{1}$ in the solid state (Kamimura, 1989). Moreover, the type of food and aflatoxin also influenced the degree of inactivation achieved. Various heat treatment reduces aflatoxin by up to $50-95 \%$ (Reddy and Rani, 2004; Hussain et al., 2011) .

\section{Sensory Evaluation of rehydrated lentil soup and} dried Bissarah

Sensory assessment is a good way to solve problems associated with food acceptance. It is useful in improving product quality SinghAckbarali and Maharaj (2014).

Dry soup should have the required quality, represented by good flavor and acceptable taste. The end product should be free from unacceptable taste and ouder Abeysinghe and Illepruma (2006). 
Rehydrated lentil soup and Bissarah Sensory evaluation according to taste, flavor, thickness, color, Trend to separation and overall acceptability of soup was determined the results illustrated in Table 12.
Table 12 demonstrated that both of the Lentil soup and Bissarah samples have high values of all the taste, flavor, thickness, color and trend to separation, in turn, the overall acceptability.

TABLE 10. Microbiological count of dried Lentil soup and Bissarah during storage period at room temperature.

\begin{tabular}{|c|c|c|c|c|c|}
\hline $\begin{array}{l}\text { Storage period } \\
\text { (Month) }\end{array}$ & Products & $\begin{array}{l}\text { Total count } \\
\quad(\mathrm{cfu} / \mathrm{g})\end{array}$ & $\begin{array}{l}\text { Thermo-philic } \\
\text { (cfu/g) }\end{array}$ & $\begin{array}{c}\text { Coliform } \\
\text { group (cfu/g) }\end{array}$ & $\begin{array}{c}\text { Yeast \& mould } \\
\quad(\mathrm{cfu} / \mathrm{g})\end{array}$ \\
\hline \multirow{2}{*}{$\mathbf{0}$} & Lentil Soup & $\begin{array}{c}2.1 \times 10^{3} \\
\pm 0.763 \times 10^{3}\end{array}$ & $29 \pm 10.5$ & nd & $26 \pm 9.8$ \\
\hline & Bissarah & $\begin{array}{c}8.3 \times 10^{2} \\
\pm 0.153 \times 10^{3}\end{array}$ & $26 \pm 6.24$ & nd & $17 \pm 7.94$ \\
\hline \multirow[b]{2}{*}{2} & Lentil Soup & $\begin{array}{c}2.6 \times 10^{4} \pm 0.305 \\
\times 10^{4}\end{array}$ & $35 \pm 13.22$ & $4 \pm 2$ & $31 \pm 13.23$ \\
\hline & Bissarah & $\begin{array}{c}2.8 \times 10^{3} \\
\pm 0.20 \times 10^{3}\end{array}$ & $42 \pm 15.87$ & nd & $23 \pm 7.93$ \\
\hline \multirow{2}{*}{4} & Lentil Soup & $\begin{array}{c}4.0 \times 10^{4} \\
\pm 0.17 \times 10^{5}\end{array}$ & $38 \pm 13.22$ & $7 \pm 3.60$ & $35 \pm 10.15$ \\
\hline & Bissarah & $\begin{array}{c}3.3 \times 10^{3} \\
\pm 0.17 \times 10^{4}\end{array}$ & $45 \pm 19.47$ & nd & $34 \pm 10.53$ \\
\hline \multirow[b]{2}{*}{6} & Lentil Soup & $\begin{array}{c}4.5 \times 10^{4} \\
\pm 0.13 \times 10^{5}\end{array}$ & $58 \pm 13.75$ & nd & $42 \pm 12.76$ \\
\hline & Bissarah & $\begin{array}{c}3.7 \times 10^{3} \\
\pm 0.12 \times 10^{4}\end{array}$ & $49 \pm 19.67$ & $5 \pm 2.65$ & $39 \pm 10.14$ \\
\hline
\end{tabular}

TABLE 11. Aflatoxins in dried lentil soup and Bissarh.

\begin{tabular}{lccccc}
\hline & \multicolumn{5}{c}{ Concentration $(\mu \mathrm{g} / \mathbf{k g})$} \\
\cline { 2 - 5 } Sample & $\mathbf{G}_{\mathbf{1}}$ & $\mathbf{G}_{\mathbf{2}}$ & $\mathbf{B}_{1}$ & $\mathbf{B}_{2}$ & Total Aflatoxin \\
\cline { 2 - 5 } Lentil Soup & 0.07 & 0.09 & 0.02 & 0.02 & 0.20 \\
Dried Bissarah & 0.16 & 0.11 & 0.25 & 0.16 & 0.68 \\
\hline
\end{tabular}

TABLE 12. Sensory evaluation of rehydrated lentil soup and Bissarah.

\begin{tabular}{|c|c|c|c|c|c|c|}
\hline Sample & $\begin{array}{c}\text { Taste } \\
\text { (10) }\end{array}$ & $\begin{array}{c}\text { Favor } \\
(10)\end{array}$ & $\begin{array}{l}\text { Thickness } \\
\text { (10) }\end{array}$ & $\begin{array}{c}\text { Color } \\
\text { (10) }\end{array}$ & $\begin{array}{l}\text { Trend to } \\
\text { separation } \\
\text { (10) }\end{array}$ & $\begin{array}{c}\text { Overall } \\
\text { Acceptability } \\
\text { (50) }\end{array}$ \\
\hline Lentil Soup & $8.75 \pm 0.90$ & $9.25 \pm 0.27$ & $8.875 \pm 0.87$ & $9.125 \pm 0.69$ & $9.00 \pm 0.78$ & 45.00 \\
\hline Bissarah & $8.50 \pm 0.96$ & $9.12 \pm 0.48$ & $9.00 \pm 0.68$ & $9.25 \pm 0.67$ & $8.50 \pm 0.90$ & 44.375 \\
\hline
\end{tabular}




\section{Conclusion}

It can be concluded that the investigated products (dried Lentil soup and Bissarah) had responsible contents of the required nutrients to meet the requirements of human for minerals. Moreover, containing a good proportion of phenolic contents, which play an active role against the fight against free radicals that are harmful to human health.

\section{References}

Abbas, Y. and Ahmad, A. (2018) Impact of Processing on Nutritional and Antinutritional Factors of Legumes: A review Annals. Food Science and Technology, 19 (2) 199-215.

Abeysinghe, C.P. and Illepruma, C.K. (2006) Formulation of an MSG (Monosodium Glutamate) Free Instant Vegetable Soup Mix. Journal of the National Science Foundation of Sri Lanka, 34, 91-95.

Acar, O., Gokmen, V., Pellegrini, N. and Fogliano, V. (2009). Direct evaluation of the total antioxidant capacity of raw and roasted pulses, nuts and seeds. European Food Research and Technology, 229, 961-969.

Aguilera, Y., Estrella, I., Benitez, V., Esteban, R.M., \& Martín-Cabrejas, M.A. (2011) Bioactive phenolic compounds and functional properties of dehydrated bean flours. Food Research International, 44, 774-780.

Alghamdi, S.S. (2009) Chemical composition of faba bean (Viciafaba L.) genotype sunder various water regimes. Pakistan Journal of Nutrition, 8, 477-482.

Al-Tonny (2012) Improvement, instantization and evaluation of some traditional Egyptian foods. MSc. Thesis, Fac. of Agric., Alexandria uni. Alexandria, Egypt.

Amarowicz, R., Pegg, R.B. (2008) Legumes as a source of natural antioxidants. European Journal of Lipid Science and Technology, 110, 865-878.

Iqbal, A., Iqtidar A. Khalil, Nadia Atteq and Muhammad S. K. (2006) Nutritional quality of important food legumes. Journal Food Chemistry, 97, 331-335.

Angel, R., Tamim, N.M., Applegate, T.J., Dhandu, A.S., Ellestad, L.E. (2002) Phytic acidchemistry: Influence on phytin-phosphorus availability and phytase efficacy. Journal of Applied Poultry Research, 11 (4), 471-480.
AOAC. (2000) Official Methods of Analysis of the Association of Official analytical chemists, $17^{\text {th }} \mathrm{ed}$., A.O.A.C., Gaithersburg, Maryland, USA.

APHA (1992) American Publish Health Association Compendium of Methods for the Microbiological Examination of Foods. Washington D.C, USA.

Brand-Williams W., Cuvelier M.E. and Berset C. (1995) Use of a free radical method to evaluate antioxidant activity.Lebensm.Wiss.Tech-No. 1: 25.

Dougherty, M., Sonbk, R., Lrive, J. and Rao, C. (1988) Oat fiber in low caloric breads sokt type cookies and pasta. Cereal Food World, 33 (5), 424-427.

Egyptian Standad (2003) Specification for dehydrated chicken and meat soup Egyptian Standard Vo. 1819.

Egyptian Standad (2007) Maximum levels for mycotoxin in food and feed.Egyptian Standard Vo. 1875/1.

El Wakeel, M. A. (2007) Ultra Structure and Functional Properties of Some Dry Mixes of Food. M.Sc. Thesis, Faculty of Agriculture, Ain Shams University, Cairo.

Fazekas, B., Tar, A., and Kovacs, M. (2005) Aflatoxin and ochratoxin A content of spices in Hungary. Food Additives and Contaminants, 22, 9, 856-863.

Hakkinen, S. H., Karenlampi, S. O., Heinonen, M., Mykkanen, H. M. and Torronen, A. R. (1998) HPLC method for screening of flavonoids and phenolic acids in berries. Journal of the Science of Food and Agriculture, 77, 543-551.

Han H. and Baik, B.K. (2008) Antioxidant activity and phenolic content of lentils (Lens culinaris), chickpeas (Cicerarietinum L.), peas (Pisumsativum L.) and soybeans (Glycine max), and their quantitative changes during processing. International Journal of Food Science and Technology, 43, 1971-1978.

Hangen, L. and Bennink, M.R. (2002) Consumption of black beans navy beans (Phaseolus vulgaris) reduced azoxymethane-induced colon cancer in rats. Journal of Nutrition and Cancer, 44,60-65.

Haug, W. and Lantzesch, H. J. (1983) Sensitive method for the rapid determination of phytate in cereals and cereal products. J. Sci. Food Agric.34, 1423-1426.

Hayat I, Ahmad A, Ahmed A, Khalil S, Gulfraz and M. Exploring (2014) The potential of red kidney beans (phaseolus vulgaris 1.) To develop protein based product for food applications. The Journal of Animal \& Plant Sciences; 24 (3), 860-868. 
Hinterthuer, A. (2016) From afterthought to staple: Expanding use of pulses as food ingredient in U.S. diets. CSA News, January, BCP:4-9.

Hussain, A., Ali, J. and Akther, S. (2011) Degradation of aflatoxinsby roasting in contaminated peanuts. Pak. J. Biochem. Mol. Biol. 44 (2), 56-59.

Jain, A.K., Kumar, S., Panwar, J.D.S. (2009) Antinutritional Factors and Their Detoxification in Pulses- A Review. Agric. Rev., 30 (1),64-70.

Kamimura, H. (1989) Removal of mycotoxins during food processing. In Mycotoxins and Phycotoxins, Ed.: S. Natori, K. Hashimoto \& Y. Ueno. Elsevier Science Publishers, Amsterdam, pp. 169-176.

Khan, I., Tabassum, F. and Khan, A. (2008).Glycemic indices and glycemic loads of various types of pulses. Pakistan Journal of Nutrition, 7 (1), 104108.

Kramer, A. and Twigg, B.A. (1974) Quality Control for the Food Industry. 3rd edition, AVI. Inc., Westport.

Krejov, A., ernohorsk, T. and Meixner, D. (2007) Elemental Analysis of Instant Soups and Seasoning Mixtures by ICP-OES. Food Chemistry, 105,242-247. http://dx.doi.org/10.1016/j. foodchem.2006.11.005.

Makun, H.A., Dutton, M.F., Njobeh, P.B., Gbodi, T.A. and Ogbadu, G.H. (2012) Aflatoxin Contamination in Foods and Feeds: A Special Focus on Africa In: Prof. Ayman Amer Eissa (Ed.) 'Trends in Vital Food and Control Engineering'ISBN: 978-953-51-04490, In Tech, retrieved on 31st July, 2012 from: http:// www.intechopen.com/books/trends-invitalfoodand-control-engineering/aflatoxin-contaminationin-foo dsand- feeds-a-special-focus-on-africa-

Mudgil, D., Barak, S. (2013) Composition, properties and health benefits of indigestible carbohydrate polymers as dietary fiber. International Journal of Biological Macromolecules, 61, 1-6.

Nakajima, Y, Tsuruma, K., Shimazawa, M., Mishima, S. and Hara, H. (2009) Comparison of bee products based on assays of antioxidant capacities. BMC Complement. Altern. Med. 9, 4.

Pandey, M., Anbidi, A. B., Siagh, S. and Singh, R. P. (2006) Nutritional Evaluation of Leafy Vegetable Paratha. Journal of human Ecology, 19,155-156.

Parca, F., Koca, O., Y., and Unay, A., (2018) Nutritional and Antinutritional Factors of Some Pulses Seed and Their Effects on Human Health. International
Journal of Secondary Metabolite, 5 (4), 331-342.

Reddy, U.M. and Rani, P.C. (2004) Effect of processing on detoxification of aflatoxins in maize.Indian $J$. Nutr. Diet. 43 (1), 54-59.

Richardson, M. (1986) Protelinase inhibitors of plants and microorganisms. Phytochemistry. 16, 159-169.

Singh, B., Singh, J. P., Kaur, A. and Singh, N., (2017a) Phenolic composition and antioxidant potential of grain legume seeds: A review, Food Research International, doi: 10.1016/j.foodres.2017.09.026.

Singh, B., Singh, P. J., Shevkani, K., Singh, N. and Kaur, A. (2017b) Bioactive constituents in pulses and their health benefits. J. Food Sci. Technol. 54 (4), 858-870.

Singh-Ackbarali, D. and Maharaj, R. (2014) Sensory Evaluation as a Tool in Determining Acceptability of Innovative Products Developed by Undergraduate Students in Food Science and Technology at the University of Trinidad and Tobago. Journal of Curriculum and Teaching, 3, 10-27.

Singleton, V.L. and Rossi, J.A., (1965) Colorimetry of phosphomolybdic phosphotungstic acid reagents. American Journal of Enology and Viticulture, 16, 144-158.

Snedecor, G. W. and Cochran, W. (1980) Statistical Methods.7th ed. Iowastate Univ. Press, Ames, USA.

Spackman, D. H., Stein, W. H. and Moore, S. (1963) Automatic recording apparatus for use in the chromatography of amino acids. Anal. Chemistry, 30 (7), 1190 - 1206

Swaminathan S. (1988) Handbook Of Food Science And Experimental Foods. Bangalore printing and publishing co. Ltd, Bangalore:127-9.

Telles, A. C., Kupski, L., and Furlong, E. B. (2017) Phenolic compound in beans as protection against mycotoxins.Food Chemistry, 214, 293-299.

Vidal-Valverde C, Frias J, Estrella I, Gorospe MJ, Ruiz R, Bacon J.(1994)Effect of processing on some antinutritional factors of lentils. Journal of Agricultural and Food Chemistry, 42,2291-2295.

Zia-ul-Haq1, M., Ahmad, S., Aslam Shad, M., Iqbal, M. S. Qayum, M. R., Ahmad, M., Luthria, D. and Amarowicz, R. (2011) Compositional studies of lentil (Lens culinarismedik) cultivars commonly grown in Pakistan. Pak. J. Bot., 43 (3), 1563-1567. 


\section{إنتاج وتقييم شوربة العدس والبيصارة المجفقة

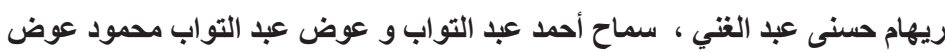

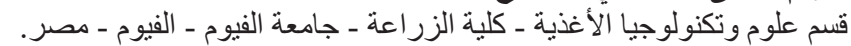

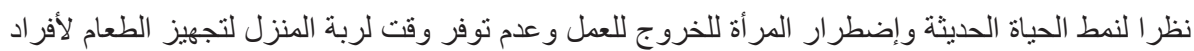

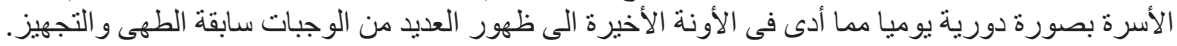

وقد إجريت هذه الدر اسة بغرض إنتاج وتجهيزبعض الوجبات الثعبية البقولية (عدس - بيصارة) فى صورة

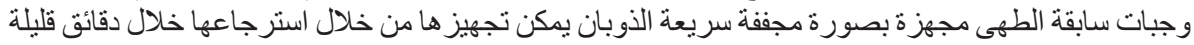

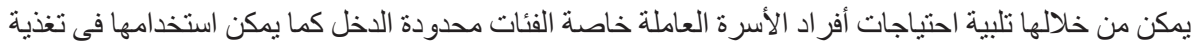

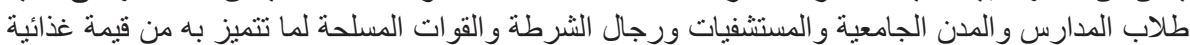
عالية بصورة رخيصة وخفة وزن وفترة صلاحية طويلة دون الحاجة لحفظها بالتبريد او التجميد.

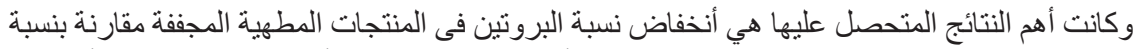

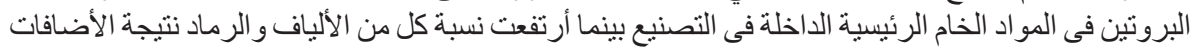

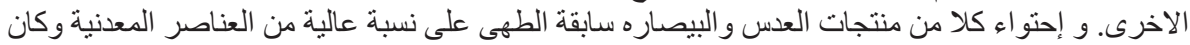

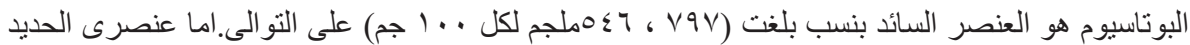

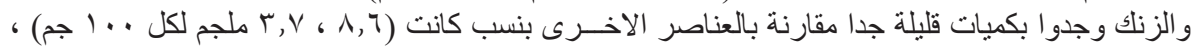

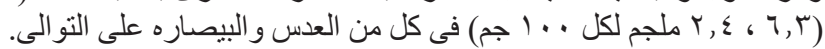

أظهرت نتائج التحليل الكروماتوجر افى فائق الأداء لفصل وتقدير محتوى المنتجات من الأحماض الأمينية

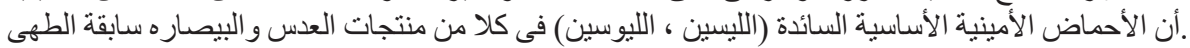

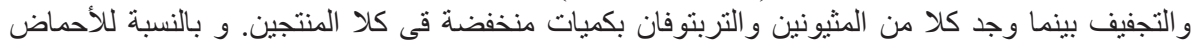
الأمينية الغير أساسية كان كلا من حامضي الجلوناميك و الأسبارتيك هما السائدان فى كلا المنتجين (العدس ،

البيصاره).

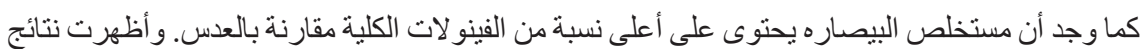

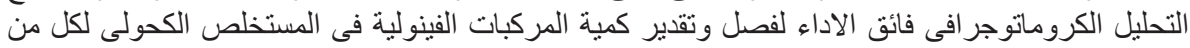

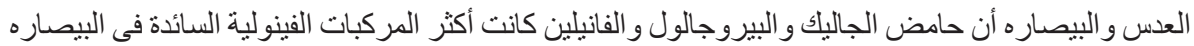

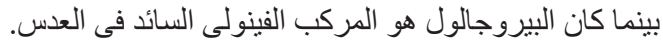

أظهرت النتائج أحتو اء الفول البلدى على محتوى عالى من حامض الفيتلك كأحد العو امل المضادة للتغذية

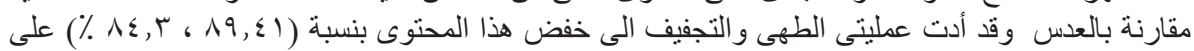
التو الى.

لوحظ من خلال در اسة تأثير أحتفاظ المنتجات المصنعة بجودتها من خلال التخزين على درجة حر ارة الغرقة

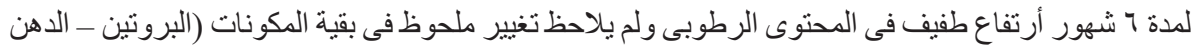

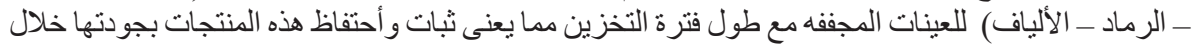

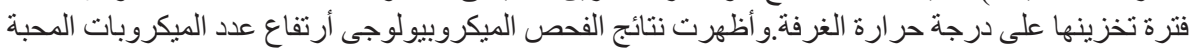

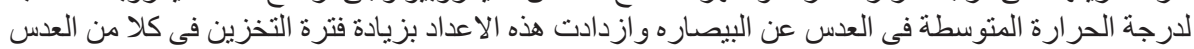
و البيصارهو وكانت في الحدود المسموح العنس بيها.

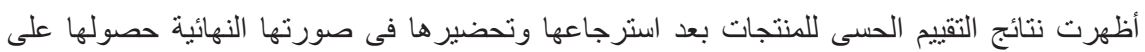
درجات عالية (ممتازة) فى مقاييس اللون ، الر ائحة ، الطعم ، القوام ، الميل للأنفصال.

مما سبق يمكن القول انها منتجات عالية الثبات و الأحتفاظ بقيمتها الغذائية خلال فترة تخزينها على درجة

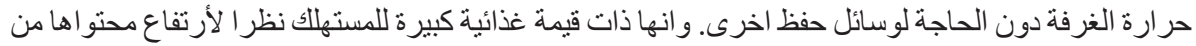

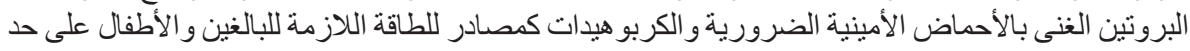

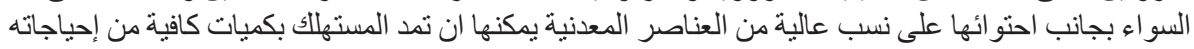

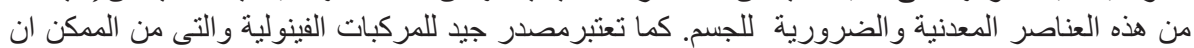

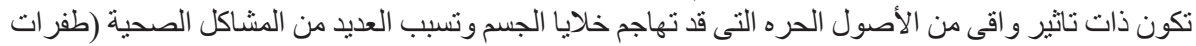
- سرطان - هرم او شيخوخة مبكرة). 